\title{
Originals
}

\section{Relationship between B-cell function and HLA antigens in patients with Type 2 (non-insulin-dependent) diabetes}

\author{
L. Groop ${ }^{1}$, P.-H. Groop ${ }^{1}$ and S. Koskimies ${ }^{2}$ \\ ${ }^{1}$ Fourth Department of Medicine, Helsinki University Hospital and ${ }^{2}$ Finnish Red Cross Blood Transfusion Service, Helsinki, Finland
}

Summary. In order to study the heterogeneity of Type 2 (noninsulin-dependent) diabetes, we determined HLA antigens and measured B-cell function as C-peptide response to intravenous glucagon in 217 patients with onset of non-ketotic diabetes after the age of 40 years. Their HLA frequencies were compared with those of Type 1 (insulin-dependent) diabetic patients and of healthy blood donors. The Type 1 diabetic patients showed a typical HLA pattern, with increased frequencies of B15, DR3, DR4, B8/B15 and DR3/DR4 and decreased frequencies of $B 7$ and DR2. The Type 2 diabetic patients could be distinguished from blood donors by increased frequencies of CW4, DR4, DR5 and DR3/DR4, and from Type 1 diabetic patients by increased frequencies of $B 7$, DR2, DR5 and decreased frequency of A9, Bw22 and DR4. Age at onset and body mass index were unrelated to HLA antigens, but the Type 2 diabetic patients with HLA-Cw4, DR5 and DR6 showed a strong family history for Type 2 diabetes. Type 2 diabetic patients with HLA-B8, DR4, B8/B15 and DR3/DR4 showed significantly lower C-peptide concentrations $(p<0.05)$ than patients without these HLA antigens. In contrast, patients with DR5 and DRw8 presented with high Cpeptide levels. Twelve patients who were positive for both DR3 and DR4 and 23 patients who were DR3/DR4 negative were followed with repeated $\mathrm{C}$-peptide determinations during a period of three years. The C-peptide concentrations of the DR3/DR4 positive patients decreased during this period, whereas there was no change in C-peptide levels in the DR3/DR4 negative patients. In conclusion, B-cell function measured as C-peptide response to glucagon correlates with HLA antigens in patients with onset of diabetes after age 40 . Impaired B-cell function seems to be associated with Type 1 diabetes-related HLA-antigens, whereas the presence of DR5 was associated with preserved B-cell function and a strong heredity for Type 2 diabetes. The results thus support the concept of heterogeneity in Type 2 diabetes. Admixture of patients with latent Type 1 diabetes can at least partially account for this heterogeneity.

Key words: Type 1 diabetes, Type 2 diabetes, C-peptide, HLAantigens, heredity.
Over the past several years, much information has accumulated which indicates that Type 2 diabetes is a heterogeneous disorder [1-3]. Probably the most critical issue is distinguishing patients with Type 1 from those with Type 2 diabetes. The definition of Type 2 diabetes is crude and based on clinical findings which are not exclusive, i. e. absence of ketosis and response to treatment with diet and/or oral antidiabetic agents [1]. However, ketosis can be absent and the patient can respond to treatment with oral antidiabetic agents in the early stages of Type 1 diabetes. Admixture of patients with late onset Type 1 diabetes within the group of Type 2 diabetes could account for part of the heterogeneity. Therefore, it would be of real clinical value to identify patients with late onset Type 1 diabetes. Islet cell antibodies are specific but insensitive markers of Type 1 diabetes and are less frequent in patients with late onset of the disease [4]. Genetic susceptibility to Type 1 diabe- tes is associated with increased frequency of the HLA antigens DR3, DR4, and the heterozygous form DR3/DR4 and decreased frequency of HLA-DR2 [5-6]. Until recently [7] Type 2 diabetes was not considered to be associated with any specific HLA antigen(s).

With this knowledge, we anticipated that it might be possible to distinguish a subgroup of patients with Type 2 diabetes who may later develop insulin dependence and thus be considered to have late onset Type 1 diabetes. We also anticipated that these patients would differ from Type 2 diabetic patients in terms of B-cell function. To test this hypothesis we determined HLA antigens and measured B-cell function in 217 patients with onset of non-ketotic diabetes after the age of 40 years. We also compared their frequencies of HLA phenotypes with those of Type 1 diabetic patients and healthy blood donors. 


\section{Subjects and methods}

Two hundred seventeen patients ( 111 females and 106 males) with onset of non-ketotic diabetes between the ages of 40 and 70 years were randomly drawn from the register of the Helsinki Diabetic Association and investigated for their B-cell function and HLA antigens. Diagnosis of diabetes had been established in all subjects in accordance with the National Diabetes Data Group criteria [1]. Patients with secondary diabetes were excluded from the study. All patients were treated with diet and/or oral antidiabetic agents when investigated. Eighty-nine patients (41\%) were additionally treated with antihypertensive drugs, and sixty patients (28\%) used digitalis because of cardiovascular disease. None of the subjects showed signs of impaired hepatic or renal function or used medication known to influence B-cell function. The patients were informed of the purpose and possible risks of the study before their voluntary consent to participate was obtained. The protocol was approved by the ethical committee of the Helsinki University Hospital.

One hundred fifteen patients (53\%) reported a first degree family history of Type 2 diabetes and 23 patients $(10 \%)$ a first degree family history of Type 1 diabetes. The patients had a mean ( \pm SD) age of $56 \pm 8$ years, duration of diabetes $7 \pm 6$ years and body mass index (BMI) 26.6 \pm 6.9 . Their mean fasting blood glucose was $9.2 \pm$ $2.5 \mathrm{mmol} / 1$ and their glycosylated haemoglobin concentration $\left(\mathrm{HbA}_{1}\right)$ was $11.8 \pm 2.8 \%$ (normal range of the assay 5.5-8.0\%). All studies were carried out in the morning after an overnight fast. Treatment with oral antidiabetic agents was stopped $48 \mathrm{~h}$ before the test. B-cell function was measured as C-peptide response to $1 \mathrm{mg}$ of glucagon intravenously [8]. Plasma C-peptide was analyzed by a modification of the radioimmunoassay described by Heding [9]. The inter-assay and intra-assay variation coefficients were 7 and $5 \%$ respectively. All patients were typed for HLA-A, B- and $\mathrm{Cw}$ antigens; additionally 121 patients were typed for DR antigens. Ninety C-peptide negative patients with long-standing Type 1 diabetes (mean age $35 \pm 6$ years) and blood donors from the same geographical area served as controls for the HLA determinations. HLA typing was performed by a standard two stage microcytotoxicity method using a total of 120 antisera defining $11 \mathrm{~A}$ locus, $20 \mathrm{~B}$ locus and $7 \mathrm{CW}$ locus specifities. Eight DR specificities were defined using a minimum of 60 antisera [10].

Twelve consecutive patients with both DR3 and DR4 ( 5 fermales and 7 males) with a mean duration of diabetes of $8 \pm 6$ years and a mean age of $58 \pm 6$ years, and 23 consecutive DR3/DR4 negative patients. (i.e. without the heterozygous form DR3/DR4; 11 females and 12 males) with a mean duration of $7 \pm 5$ years and a mean age of $55 \pm$ 6 years, were followed with repeated $\mathrm{C}$-peptide determinations during a period of 3 years (Fig. 2).

\section{Statistical analysis}

Values are expressed as means \pm SD or as means \pm SEM. Statistical analysis was performed by analysis of variance, chi-square test or Fisher's exact probability test by the use of a BMDP computer program [11]. When comparing differences in HLA phenotype frequencies, the obtained $p$ values were corrected for the number of antigens defined in the sample at the locus in question. A $p$ value of $<0.05$ was considered statistically significant.

\section{Results}

The frequencies of HLA-A and -B antigens in blood donors, Type 1 and Type 2 diabetic subjects are shown in Table 1, and those of Cw and DR antigens in Tables 2 and 3 respectively. The Type 1 diabetic patients presented with higher frequencies of $\mathrm{A} 9\left(X^{2}=10.77\right.$; $p=0.013), \mathrm{B} 15\left(X^{2}=18.91 ; p=0.000\right), \mathrm{B} 8 / \mathrm{B} 15\left(X^{2}=\right.$ $23.05 ; p=0.000)$, Cw3 $\left(X^{2}=9.19 ; p=0.018\right), \mathrm{DR} 3$
Table 1. Frequencies of HLA-A and -B antigens in blood donors, Type 1 and Type 2 diabetic patients

\begin{tabular}{|c|c|c|c|c|c|c|}
\hline \multirow[t]{2}{*}{$\begin{array}{l}\text { HLA } \\
\text { antigen }\end{array}$} & \multicolumn{2}{|c|}{$\begin{array}{l}\text { Blood donors } \\
(n=900)\end{array}$} & \multicolumn{2}{|c|}{$\begin{array}{l}\text { Type } 1 \\
\text { diabetic patients } \\
(n=90)\end{array}$} & \multicolumn{2}{|c|}{$\begin{array}{l}\text { Type } 2 \\
\text { diabetic patients } \\
(n=217)\end{array}$} \\
\hline & $n$ & $\%$ & $n$ & $\%$ & $n$ & $\%$ \\
\hline A1 & 181 & 20.1 & 19 & 21.1 & 41 & 18.9 \\
\hline A2 & 486 & 54.0 & 58 & 64.4 & 126 & 58.1 \\
\hline A3 & 400 & 44.4 & 36 & 40.0 & 86 & 39.6 \\
\hline A9 & 146 & 16.2 & $27^{\mathrm{a}}$ & 30.0 & $33^{c}$ & 15.2 \\
\hline A10 & 70 & 7.8 & 0 & 0 & 15 & 7.0 \\
\hline A11 & 79 & 8.8 & 4 & 4.4 & 10 & 4.6 \\
\hline Aw19 & 176 & 19.6 & 9 & 10.0 & 48 & 22.1 \\
\hline A28 & 102 & 11.3 & 12 & 13.3 & 27 & 12.4 \\
\hline B5 & 107 & 11.9 & 8 & 8.9 & 21 & 9.7 \\
\hline B7 & 219 & 24.3 & $6^{\mathrm{b}}$ & 6.7 & $46^{d}$ & 21.2 \\
\hline B8 & 180 & 20.0 & 27 & 30.0 & 48 & 22.1 \\
\hline B12 & 139 & 15.4 & 12 & 13.3 & 33 & 15.2 \\
\hline B13 & 54 & 6.0 & 4 & 4.4 & 17 & 7.9 \\
\hline B14 & 3 & 0.3 & 0 & 0 & 2 & 0.9 \\
\hline B15 & 181 & 21.1 & $36^{b}$ & 40.0 & 65 & 30.0 \\
\hline B16 & 129 & 14.3 & 12 & 13.3 & 22 & 10.2 \\
\hline B17 & 39 & 4.6 & 1 & 1.1 & 9 & 4.1 \\
\hline B18 & 90 & 10.0 & 8 & 8.9 & 19 & 8.8 \\
\hline B21 & 4 & 0.4 & 0 & 0 & 2 & 0.9 \\
\hline Bw22 & 45 & 5.0 & 10 & 11.1 & $4^{d}$ & 1.8 \\
\hline B27 & 126 & 14.0 & 3 & 3.3 & 28 & 12.9 \\
\hline B35 & 245 & 27.2 & 27 & 30.0 & 73 & 33.6 \\
\hline B 40 & 161 & 17.9 & 21 & 23.3 & 35 & 16.1 \\
\hline B8 $8 / B 15$ & 23 & 2.6 & $11^{\mathrm{b}}$ & 12.2 & 10 & 4.6 \\
\hline
\end{tabular}

${ }^{\mathrm{a}} p<0.01 ;{ }^{\mathrm{b}} p<0.001$ vs blood donors; ${ }^{\mathrm{c}} p<0.01 ;{ }^{\mathrm{d}} p<0.001$ vs Type 1 diabetic patients

Table 2. Frequencies of HLA-Cw antigens in blood donors, Type 1 and Type 2 diabetic patients

\begin{tabular}{|c|c|c|c|c|c|c|}
\hline \multirow[t]{2}{*}{$\begin{array}{l}\text { HLA } \\
\text { antigen }\end{array}$} & \multicolumn{2}{|c|}{$\begin{array}{l}\text { Blood donors } \\
\left(n={ }^{\mathrm{a}} 480,{ }^{\mathrm{b}} 330\right)\end{array}$} & \multicolumn{2}{|c|}{$\begin{array}{l}\text { Type } 1 \\
\text { diabetic patients } \\
(n=90)\end{array}$} & \multicolumn{2}{|c|}{$\begin{array}{l}\text { Type } 2 \\
\text { diabetic patients } \\
(n=217)\end{array}$} \\
\hline & $n$ & $\%$ & $n$ & $\%$ & $n$ & $\%$ \\
\hline Cw1 & 69 & 14.4 & 9 & 10.8 & 28 & 15.0 \\
\hline $\mathrm{Cw} 2$ & 32 & 6.7 & 10 & 12.0 & 20 & 10.7 \\
\hline Cw3 & 155 & 32.1 & $44^{1}$ & 53.0 & 79 & 42.3 \\
\hline Cw4 & 65 & 19.7 & 29 & 32.2 & $72^{1}$ & 33.2 \\
\hline Cw5 & 35 & 10.6 & 9 & 10.8 & 10 & 5.5 \\
\hline Cw6 & 35 & 10.6 & 5 & 6.0 & 25 & 13.4 \\
\hline Cw7 & - & - & 15 & 18.1 & 23 & 10.5 \\
\hline
\end{tabular}

$\mathrm{a} / \mathrm{b}$ The number of tested blood donors for $\mathrm{Cw} 1-\mathrm{Cw} 3$ and $\mathrm{Cw} 4-\mathrm{Cw} 6$ respectively,

${ }^{1} p<0.01$ vs blood donors

$\left(X^{2}=14.25 ; \quad p=0.002\right), \quad$ DR4 $\quad\left(X^{2}=36.88 ; \quad p=\right.$ $0.000), \mathrm{DR} 3 / \mathrm{DR} 4\left(X^{2}=27.63 ; p=0.000\right)$ and lower frequencies of B7 $\left(X^{2}=14.54 ; p=0.004\right)$ and DR2 $\left(X^{2}=\right.$ $22.77 ; p=0.000$ ) than blood donors. The Type 2 diabetic patients showed higher frequencies of HLA-Cw4 $\left(X^{2}=12.68 ; p=0.004\right)$, DR4 $\left(X^{2}=9.17 ; p=0.020\right)$, DR5 $\left(X^{2}=18.25 ; p=0.000\right)$ and DR3/DR4 $\left(X^{2}=7.99\right.$; $p=0.038)$ than the blood donors. They differed from Type 1 diabetic patients with respect to lower frequency of HLA-A9 $\left(X^{2}=9.55 ; p=0.044\right)$, DR2 $\left(X^{2}=10.33\right.$; 
Table 3. Frequencies of HLA-DR antigens in blood donors, Type 1 and Type 2 diabetic patients

\begin{tabular}{|c|c|c|c|c|c|c|}
\hline \multirow[t]{2}{*}{$\begin{array}{l}\text { HLA } \\
\text { antigens }\end{array}$} & \multicolumn{2}{|c|}{$\begin{array}{l}\text { Blood donors } \\
(n=322)\end{array}$} & \multicolumn{2}{|c|}{$\begin{array}{l}\text { Type } 1 \\
\text { diabetic patients } \\
(n=90)\end{array}$} & \multicolumn{2}{|c|}{$\begin{array}{l}\text { Type } 2 \\
\text { diabetic patients } \\
(n=121)\end{array}$} \\
\hline & $n$ & $\%$ & $n$ & $\%$ & $n$ & $\%$ \\
\hline DR1 & 120 & 37.3 & 23 & 25.3 & 40 & 33.1 \\
\hline DR2 & 107 & 33.2 & $7^{\mathrm{c}}$ & 8.1 & $30^{\mathrm{c}}$ & 24.8 \\
\hline DR3 & 102 & 31.6 & $48^{c}$ & 55.2 & 48 & 39.7 \\
\hline DR4 & 89 & 27.6 & $56^{c}$ & 64.4 & $51^{\mathrm{d}}$ & 42.1 \\
\hline DR5 & 20 & 6.2 & 6 & 6.9 & $24^{\mathrm{b} / \mathrm{d}}$ & 19.8 \\
\hline DRw6 & 17 & 5.2 & 5 & 5.5 & 5 & 4.1 \\
\hline DR7 & 57 & 17.7 & 9 & 10.3 & 22 & 18.2 \\
\hline DRw8 & 41 & 12.7 & 7 & 8.1 & 5 & 5.3 \\
\hline DR3/DR4 & 426 & 8.0 & $26^{\mathrm{c}}$ & 29.9 & $21^{\mathrm{a}}$ & 17.4 \\
\hline
\end{tabular}

${ }^{\mathrm{a}} p<0.05 ;{ }^{\mathrm{b}} p<0.01 ;{ }^{\mathrm{c}} p<0.001$ vs blood donors; ${ }^{\mathrm{d}} p<0.05$; ${ }^{\mathrm{e}} p<0.01$ vs Type 1 diabetic patients

Table 4. Age at onset of diabetes, body mass index (BMI), first degree family history of Type 1 and Type 2 diabetes and post-glucagon Cpeptide concentrations in Type 2 diabetic patients with and without a certain HLA antigen

\begin{tabular}{|c|c|c|c|c|c|}
\hline \multirow{2}{*}{$\begin{array}{l}\text { HLA } \\
\text { antigen }\end{array}$} & \multirow{2}{*}{$\begin{array}{l}\text { Age at } \\
\text { onset } \\
\text { (years) }\end{array}$} & \multirow[t]{2}{*}{ BMI } & \multicolumn{2}{|c|}{ Family history of } & \multirow{2}{*}{$\begin{array}{l}\text { C-peptide } \\
(\mathrm{nmol} / 1)\end{array}$} \\
\hline & & & $\begin{array}{l}\text { Type } 2 \\
\text { diabetes } \\
(\%)\end{array}$ & $\begin{array}{l}\text { Type } 1 \\
\text { diabetes } \\
(\%)\end{array}$ & \\
\hline B7 & $48 \pm 2$ & $28.3 \pm 0.8$ & 45.8 & 14.6 & $1.21 \pm 0.09^{\mathrm{a}}$ \\
\hline B8 & $50 \pm 1$ & $27.8 \pm 0.7$ & 57.1 & 2.9 & $1.14 \pm 0.08$ \\
\hline B15 & $51 \pm 1$ & $27.1 \pm 0.5$ & 50.8 & 12.7 & $1.15 \pm 0.09$ \\
\hline $\mathrm{B} 8 / \mathrm{B} 15$ & $52 \pm 3$ & $24.7 \pm 1.3$ & 55.6 & 11.1 & $0.65 \pm 0.14^{b}$ \\
\hline $\mathrm{Cw} 4$ & $50 \pm 1$ & $26.4 \pm 0.5$ & $74.1^{\mathrm{c}}$ & 24.1 & $1.14 \pm 0.07$ \\
\hline DR1 & $49 \pm 2$ & $27.2 \pm 0.7$ & 63.2 & 10.5 & $0.99 \pm 0.06$ \\
\hline DR2 & $48 \pm 1$ & $26.4 \pm 1.0$ & 50.0 & 4.2 & $1.04 \pm 0.10$ \\
\hline DR3 & $50 \pm 1$ & $26.3 \pm 0.6$ & 50.0 & 9.4 & $0.89 \pm 0.07$ \\
\hline DR4 & $49 \pm 1$ & $26.9 \pm 0.6$ & 47.9 & 10.4 & $0.83 \pm 0.07^{\mathrm{a}}$ \\
\hline DR5 & $48 \pm 1$ & $27.9 \pm 0.8$ & $75.0^{\mathrm{a}}$ & 12.5 & $1.19 \pm 0.14^{a}$ \\
\hline DRw6 & $51 \pm 3$ & $26.4 \pm 1.8$ & $80.0^{\mathrm{b}}$ & 0 & $0.78 \pm 0.14$ \\
\hline Dr7 & $50 \pm 2$ & $26.9 \pm 0.9$ & 45.5 & 22.7 & $0.95 \pm 0.08$ \\
\hline DRw8 & $56 \pm 3$ & $27.2 \pm 1.3$ & 71.4 & 14.3 & $1.39 \pm 0.27^{\mathrm{a}}$ \\
\hline DR3/DR4 & $51 \pm 2$ & $26.3 \pm 0.8$ & 45.8 & 14.6 & $0.74 \pm 0.09^{\mathrm{a}}$ \\
\hline $\begin{array}{l}\text { All } \\
\text { patients }\end{array}$ & $49 \pm 1$ & $26.6 \pm 0.5$ & 53.1 & 10.4 & $1.0 \pm 0.04$ \\
\hline
\end{tabular}

${ }^{\mathrm{a}} p<0.05 ;{ }^{\mathrm{b}} p<0.01 ;{ }^{\mathrm{c}} p<0.001$ vs patients without the particular HLA antigen

$p=0.012), \operatorname{DR} 4\left(X^{2}=8.32 ; p=0.031\right)$ and a tendency to higher frequency of DR5 $\left(X^{2}=7.18 ; p=0.056\right)$. Age at onset and body mass index were not related to HLA antigens (Table 4). However, a first degree family history of Type 2 diabetes was more common among patients with the HLA antigens Cw4, DR5 and DRw6 than among patients without these HLA antigens $(p<0.05$, $p<0.01$ and $p<0.001$ respectively). The mean post-glucagon C-peptide concentration of all patients was $1.0 \pm 0.04 \mathrm{nmol} / 1$, and that of age- and weight-matched healthy subjects was $1.30 \pm 0.08 \mathrm{nmol} / 1(n=34)$. Patients who were positive for HLA-B8, DR4, DR3/DR4 and B8/B15 showed significantly lower glucagon stimulated $\mathrm{C}$-peptide concentrations than patients without these HLA antigens $(p<0.05)$ (Table 4, Fig. 1). In con-

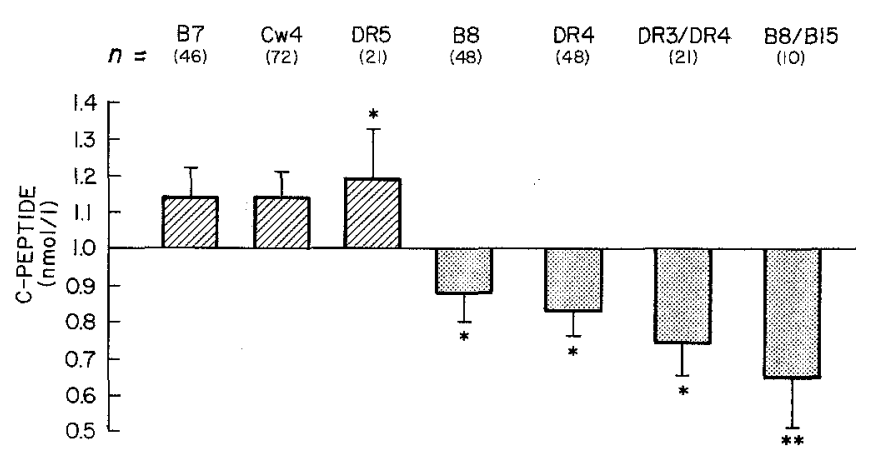

Fig. 1. C-peptide response to glucagon in relation to HLA antigens in patients with onset of non-ketotic diabetes after age 40 . The bars represent the difference from the mean of all patients. The number of studied patients with a given HLA antigen is given within brackets. Patients with $\mathrm{B} 8 / \mathrm{B} 15$ and DR3/DR4 were heterozygous for these phenotypes. ${ }^{*} p<0.05 ; * * p<0.02$ vs patients without the HLA-antigen(s)

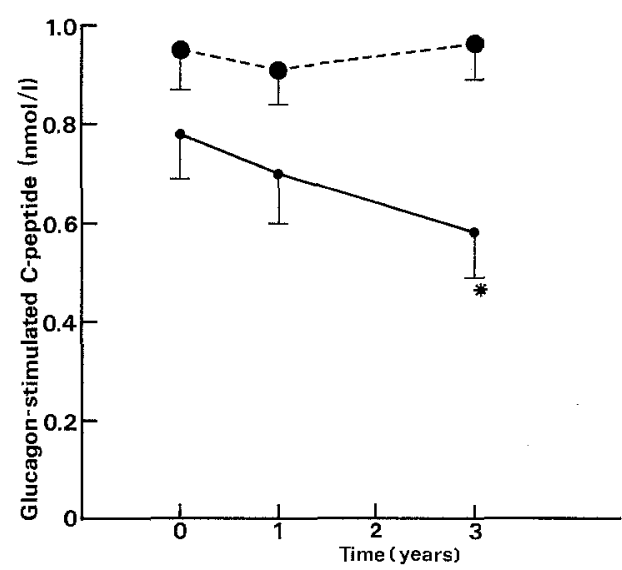

Fig. 2. C-peptide response to glucagon decreased significantly in 12 patients with both DR3 and DR4 during a follow-up period of three years $(p<0.01)$. In contrast, there was no change in post-glucagon $C$-peptide concentrations of 23 patients who were negative for both DR 3 and DR4 during the same period. * $p<0.01$; significance of difference from the beginning of the follow-up period. DR3/DR4$(\bullet)$, DR3/DR4 ${ }^{+}(\bullet)$

trast, the HLA antigens DR5 and DRw8 were associated with increased C-peptide response to glucagon $(p<$ 0.05 ). The C-peptide concentrations of the DR3/DR4 positive patients decreased significantly during the follow-up period $(p<0.01)$, whereas there was no change of C-peptide concentrations with time in the DR3/DR4 negative patients (Fig. 2).

\section{Discussion}

The Type 1 diabetic patients in this study showed a typical HLA pattern, with the known increase in HLADR3, DR4, DR3/DR4 and decrease in DR2. Indeed, $90 \%$ of them had either DR3 or DR4, which is similar to 
those reported in Danish [12] and British [6] studies. The DR frequencies in the blood donors were similar to those reported in other Caucasian populations [6, 13]; suggesting that the deviation in HLA antigens seen in the diabetic patients were related to the disease itself. The patients with Type 2 diabetes showed a HLA pattern which partially resembled that of Type 1 diabetes (increased frequencies of DR4 and DR3/DR4), partially that of the background population (no decrease in the frequency of B7 and DR2). This intermediate position of Type 2 diabetes in terms of HLA antigens can be interpreted in two ways. Firstly, Type 2 diabetes does not differ from the background population with respect to HLA antigens, and the increase in DR4 and DR3/DR4 reflects admixture of patients with late onset of Type 1 diabetes within the spectrum of Type 2 diabetes. This is supported by the findings of similar frequencies of B7 and DR2 in Type 2 diabetic patients as in blood donors, and the increase in the Type 1-related HLA antigens thus reflects admixture. Secondly, Type 2 diabetes is a heterogeneous disease including several subsets, one of them showing a HLA pattern similar to that seen in Type 1 diabetes. The concept of heterogeneity is supported by the increased frequency of $\mathrm{Cw} 4$ and DR5 in the Type 2 diabetic patients, the frequency of DR5 also being higher than in Type 1 diabetes. Interestingly, patients with Cw4 and DR5 showed an increased frequency of a first degree family history of Type 2 diabetes, suggesting a strong genetic background in Type 2 diabetic patients with these HLA antigens. To further address the question of admixture or heterogeneity, we analysed B-cell function in the Type 2 diabetic patients in relation to HLA antigens. In the case of admixture, we assumed that patients with Type 1-related HLA antigens would show some degree of impaired Bcell function. This was, in fact, what we observed; patients with B8, DR4 and especially B8/B15 and DR3/DR4 showed decreased C-peptide response to glucagon. Furthermore, the presence of DR3/DR4 predicted a progressive decrease in B-cell function over time. On the other hand, patients with the "Type 2-related" HLA antigen DR5 presented with increased C-peptide response to glucagon. Factors other than impaired $\mathrm{B}$-cell function must be involved in the pathogenesis of diabetes in these patients.

In conclusion, our results indicate a relationship between B-cell function and HLA antigens in patients with onset of non-ketotic diabetes after the age of 40 years. They also support the view that Type 2 diabe- tes is a heterogeneous disease. Admixture of patients with latent Type 1 diabetes within the group of Type 2 diabetes could partially contribute to this heterogeneity.

Acknowledgements. We are indebted to R. Pelkonen, M.D. for his support with planning of the study, to Ms. S. Heikkinen, Ms. O. Könönen and Ms. T. Riikonen for their skillful technical assistance and to all patients for their participation in the study. The study was supported by grant from the Finnish Diabetes Research Foundation and from the Finnish Medical Society (Finska Läkaresällskapet).

\section{References}

1. National Diabetes Data Group (1979) Classification and diagnosis of diabetes mellitus and other categories of glucose intolerance. Diabetes 28: 1039-1057

2. Fajans SS, Cloutier MC, Crowther RL (1978) Clinical and etiologic heterogeneity of idiopathic diabetes mellitus. Diabetes 27 : $1112-1125$

3. Groop L (1982) Heterogeneity of Type 2 diabetes. A study of clinical, genetic, immunological and metabolic aspects. Thesis, University of Helsinki

4. Bottazzo GF (1984) Beta-cell damage in diabetic insulitis: are we approaching a solution? Diabetologia 26: 241-249

5. Cudworth AG (1978) Type 1 diabetes mellitus. Diabetologia 14: 281-291

6. Wolf E, Spencer KM, Cudworth AG (1983) The genetic susceptibility to Type 1 (insulin-dependent) diabetes: analysis of the HLADR association. Diabetologia 24: 224-230

7. Groop L, Koskimies S, Pelkonen R, Tolppanen EM (1983) Increased frequency of HLA-Cw4 in type 2 diabetes. Acta Endocrinol 104: 475-478

8. Faber OK, Binder C (1977) C-peptide response to glucagon. A test for residual beta-cell function. Diabetes 26: 605-610

9. Heding LG (1975) Radioimmunological determination of C-peptide in serum. Diabetologia 11: 541-548

10. Ray JG, Hare DB, Pedersen PD, Mullaly DI (eds) (1976-1977) NIAID Manual of tissue typing techniques. Institute of Health, Bethesda, MD, DHEW 76-545, p 22

11. Dixon WJ (ed) (1981) BMDP statistical software. University of California Press, Berkely

12. Platz P, Jakobsen BK, Marling N, Ryder LP, Svejgaard A, Thomsen M, Christy M, Kromann H, Benn J, Nerup J, Green A, Hange M (1981) HLA-D and DR-antigens in genetic analysis of insulin dependent diabetes mellitus. Diabetologia 21: 108-115

13. Jakobsen BK, Morling N, Platz P, Ryder LP, Thomsen M, Svejgaard A (1981) HLA-DR phenotype and HLA-B, DR haplotype frequencies in 704 unrelated Danes. Tissue antigens 18:270-275

Received: 21 March 1985

and in revised form: 29 August 1986

Dr. Leif Groop

Fourth Department of Medicine

Helsinki University Hospital

Unioninkatu 38

SF-00170 Helsinki

Finland 